UDC 363.084.522.2.

\title{
DYNAMICS OF GROWTH, DEVELOPMENT AND REPRODUCTIVE ABILITY OF HEIFERS OF DIFFERENT LINES OF THE ZNAMYANSKY TYPE POLISKA MEAT BREED
}

\author{
M. Tsukanova \\ Kharkiv State Zooveterinary Academy, Kharkiv, Ukraine
}

Article info

Received 06.03.2019

Received in revised form

20.03.2019

Accepted 01.04.2019

Kharkiv State Zooveterinary Academy

Academic st. 1, Mala

Danilovka, Dergachi district, Kharkiv region, Ukraine,

62341

E-mail:

mari9687@gmail.com
Tsukanova, M. (2019). Dynamics of growth, development and reproductive ability of heifers of different lines of the znamyansky type poliska meat breed. Veterinary science,technologies of animal husbandry and nature management, 3, 59-65. doi: 10.31890/vttp.2019.03.09.

The article presents the results of the study of the growth and development and reproductive abilities of heifers of different linear origin of the Znamyansky type Poliska meat breed

Experimental research was carried out in the Agrofirma "Kolos" Znamyansky district, Kirovograd region. The object of research was the heifers of the Znamyansky type of different lines: I - control - animals, which are not included in the experimental lines, II - Mazun 6; IIIRadyst 113; IV - Darovanyy 400.

As a result of the carried out research, we found out that heifers of control and experimental groups at identical conditions of feeding and maintenance, have shown various intensity of growth. Heifers of experimental groups by live weight indicators in all age periods exceeded peers of the control group with a true difference. Among the experimental groups there was an obvious advantage for the animals of the third experimental group.

The same tendency is observed in the indicators of the daily average and relative increments. High daily average increment of the animals of the third experimental group was $828,8 \mathrm{~g}$ per day during the period of 12-15 months.

Comparing the body measurements of heifers of different experimental groups, we can note the advantage of animals of the III experimental group in all altitude and latitude parameters. The other three groups had lower and rather similar indicators. In general, the animals are quite large, harmoniously built, with a strong, but not massive skeleton, which is confirmed by the indicators of animal physique.

By physique indexes the highest marks were given to heifers of III and IV experimental groups. They had higher indexes of physique such as breast, index of blockiness, which characterizes their better meat forms.

The growth energy of animals in meat cattle breeding is an indicator that has a direct impact on reproduction ability, because a fully developed animal is able to reach puberty quite 
early and give a healthy offspring every year. By the indexes of reproductive ability of heifers it was found out that there are certain differences between heifers of different origins.

Animals of different genotypes had quite different indicators of live weight during the first hunting. The animals of the third experimental group had the highest weight $333,9 \mathrm{~kg}$, the animals of the first control group had the lowest weight 230,4 $\mathrm{kg}$. Heifers of the third experimental group were also characterized by a high rate of fertilization from the first mating in comparison with other groups with a true difference. By the indicators of duration of pregnancy, there is no significant difference between the genotypes.

Key words: type, breed, age, growth, development, meat cattle breeding, line, reproducible ability.

\title{
ДИНАМИКА РОСТА, РАЗВИТИЯ И ВОСПРОИЗВОДИТЕЛЬНОЙ СПОСОБНОСТИ ТЕЛОК РАЗНОГО ПРОИСХОЖДЕНИЯ ЗНАМЕНСКОГО ТИПА ПОЛЕССКОЙ МЯСНОЙ ПОРОДЫ
}

\author{
М. А. Цуканова \\ Харьковская государственная зооветеринарная академия, Харьков, Украина
}

В статье изложены результаты изучения роста развития и воспроизводительной способности телок разного линейного происхождения знамянского типа полесской мясной породы.

Экспериментальные исследования были проведены в Агроффирме «Колос» Знаменского района Кировоградской области. Объектом исследований были телки знаменского типа различных линий: I - контрольная, это животные, которые не вошли в опытные линии, II опытная - Мазуна 6; III опытная - Радиста 113; IV опытная - Дарованого 400.

В результате проведенных исследований установлено, что телки контрольной и опытных групп при одинаковых условиях кормления и содержания, показали различную интенсивность роста. Так телки опытных групп по показателям живой массы во все возрастные периоды превышали сверстниц контрольной группы с достоверной разницей. Среди опытных групп несомненное преимущество было у животных III опытной группы.

Такая же тенденция наблюдается и по показателям среднесуточных и относительных приростов. Высокий среднесуточный прирост у животных III опытной группы составил 828, 8 г в сутки в период 12-15 месяцев.

Сравнивая промеры тела телок различных опытных групп можно отметить преимущество животных III опытной группы по всем параметрам высоты и ширины. Остальные три группы имели более низкие и довольно близкие показатели. В целом животные достаточно крупные, гармонично сложенные, с крепким, но не массивным костяком, что подтверждается показателями индексов телосложения животных.

По индексам телосложения высиую оценку получили телки III и IV опытных групп. Они имели более высокие показатели по таким индексам телосложения как грудной, сбитости, что характеризует их лучшие мясные формы.

Энергия роста животных в мясном скотоводстве это показатель, который непосредственно влияет на воспроизводительную способность, потому что полноценно развитое животное способно довольно рано достичь половой зрелости и давать здоровое потомство каждый год. По показателям воспроизводительной способности телок установлено, что между телками разного происхождения есть определенные различия.

Животные разных генотипов при проявлении первой охоты имели достаточно разные показатели живой массы. Самая большая 333,9ка была у животных III опытной группы, а самая низкая 230,4 ке в I контрольной. Телки III опытной группы также характеризовались высоким показателем оплодотворенности от первого спаривания по сравнению с ровесницами других групп при достоверной разнице. По показателям продолжительности стельности существенной разницы между генотипами не установлено.

Ключевые слова: тип, порода, возраст, рост, развитие, мясное скотоводство, линия, воспроизводительная способность 


\title{
ДИНАМІКА РОСТУ, РОЗВИТКУ ТА ВІДТВОРНОЇ ЗДАТНОСТІ ТЕЛИЦЬ РІЗНОГО ПОХОДЖЕННЯ ЗНАМ'ЯНСЬКОГО ТИПУ ПОЛІСЬКОЇ М'ЯСНОЇ ПОРОДИ
}

\author{
М.О. Цуканова \\ Харківська державна зооветеринарна академія, м. Харків, Україна
}

\begin{abstract}
У статті висвітлені результати вивчення росту, розвитку та відтворної здатності телиць різного лінійного походження знам'янського типу поліської м'ясної породи. За даними досліджень кращими за показниками росту та розвитку були телиці лінії Радиста 113, ці тварини також мали перевагу за показниками відтворної здатності у порівнянні з іншими групами.
\end{abstract}

Ключові слова: тип, порода, вік, ріст, розвиток, м'ясне скотарство, лінія, відтворна здатність.

\section{Вступ}

В останні роки в Україні різко скорочується виробництво яловичини, особливо низький її відсоток отримують від тварин спеціалізованих м'ясних порід (Sen, Ruban, Getya, \& Nesterov, 2014; Vlasova,2015; Suprun, Ruban \& Getya, 2016; Shust, 2018). Нажаль питанню розвитку м'ясного скотарства уваги зі сторони держави майже не приділяється. Така ситуація $є$ загрозливою $з$ точки зору продовольчої безпеки держави, бо саме дефіцит товарів тваринного походження вітчизняного виробництва свідчить про залежність держави від зовнішніх виробників і незахищеність населення в разі припинення цих поставок (Dibrova \& Kukhar, 2014;--Pidorycheva, 2014; Zinovchuk, Rud, 2016; Kernasiuk, 2016; Gladij, Sychevs'ky, 2018). Ситуація ускладняється тим, що багато вітчизняних м'ясних порід знаходяться на такому етапі, що не прийняття найближчім часом комплексу заходів по їх збереженню та розвитку може призвести до того, що вони зовсім зникнуть( Reznikova, 2016; Kruglyak \& Martynyuk, 2016; Polupan, Basovskyi, Rieznykova \& Reznikova, 2017; Prudnikov, Popova. \& Tsukanova, 2018).

Актуальність теми. Знам'янський тип поліської породи був створений у 2009 році, однак кількість поголів'я цієї худоби, нажаль, з року в рік зменшується. Незважаючи на це, селекційні процеси в середині типу постійно проводяться, досліджуються та аналізуються господарсько-біологічні особливості різних статевовікових груп та створюються плани та програми по вдосконаленню ліній та сімейств (Prudnikov, Popova, 2001; Pochukalin, Reznikova, Priyma, \& Rizun, 2016).
Отже дослідження росту, розвитку та відтворної здатності телиць різних лінії актуальне і важливе питання.

Аналіз останніх досліджень $і$ публікацій. Практика розвитку тваринництва в США, Канаді, Франції, Австрії, Італії і інших розвинених країнах світу показує, що подолати проблему забезпечення населення м'ясом можливо за рахунок розвитку саме спеціалізованого м'ясного скотарства (Gregory, Grandin, 2007; Herring, 2014; Greenwood, Clayton \& Bell, 2017; Gokirmakli, Bayram, 2017). Однак необхідними умовами розвитку даної галузі $є$ наявність порід м'ясної худоби, які добре пристосовані до природно-кліматичних умов певного регіону (Hladiy, Polupan, Kovtun \& Borodai, 2018). Окрім того успішний розвиток галузі можливий лише при інтенсивному росту, розвитку тварин та високих відтворних якостях наявного поголів'я. Отже високого рівня рентабельності можливо досягти в тому випадку, коли кожна новонароджена телиця буде інтенсивно вирощуватись та перший раз буде спарована у віці 15-17 місяців і в подальшому кожного року даватиме теля (Honcharova, 2006).

Meта роботи. Провести оцінку показників росту, розвитку телиць різних ліній знам'янського типу поліської м'ясної породи, а також оцінити репродуктивні функції телиць.

Завдання дослідження. Порівняти показники росту, розвитку та відтворної здатності телиць різних ліній знам'янського типу поліської м'ясної породи

\section{Матеріал і методи досліджень}

Експериментальні дослідження були проведені в Агрофрірмі «Колос» Знам'янського району Кіровоградської області. Об’єктом досліджень були 
телиці знам'янського типу різних ліній. Для проведення досліджень було створено 4 групи тварин: I контрольна це тварини, які не увійшли до дослідних ліній, II дослідна - Мазуна 6; III дослідна - Радиста 113; IV дослідна - Дарованого 400.

Для визначення показників росту, розвитку та відтворної здатності використовувалися загальноприйняті інструментальні, розрахункові та окомірні методи дослідження.

\section{Результати та їх обговорення}

В результаті проведених досліджень встановлено, що телиці контрольної та досліджуваних груп за однакових умов годівлі й утримання, показали різну інтенсивність росту (табл. 1).

Таблиця 1

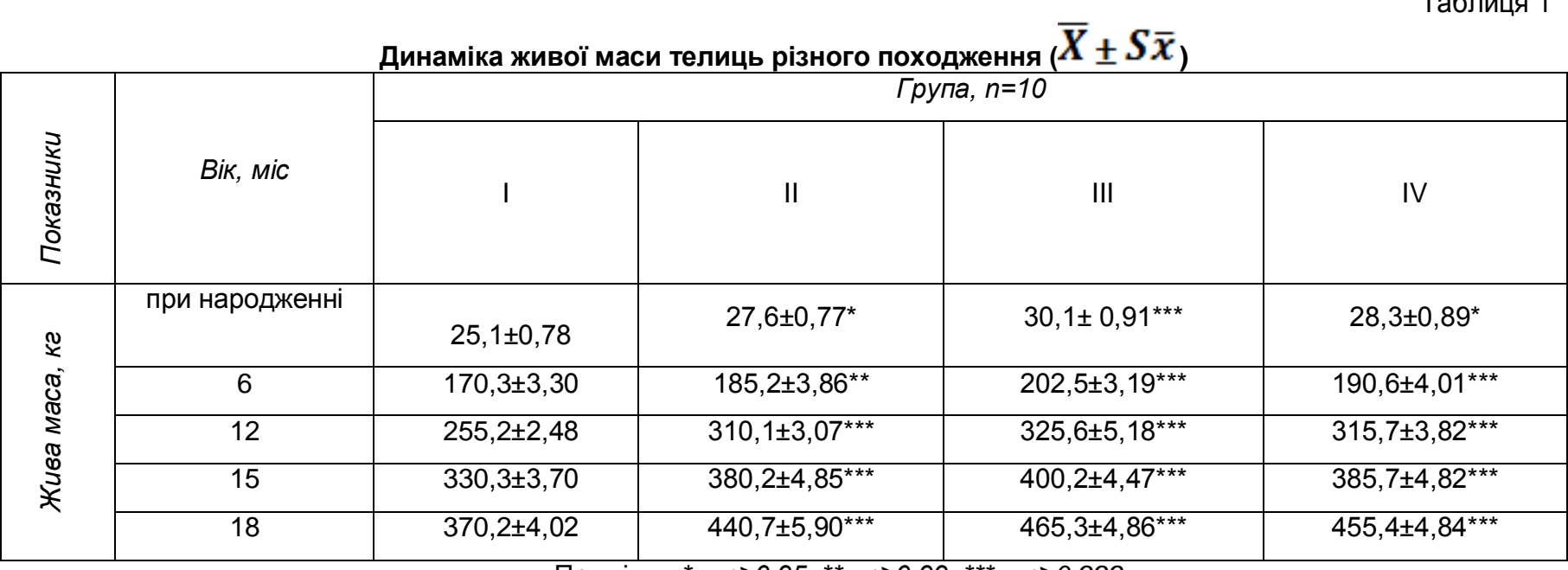

Примітки: * $-p \geq 0,95,{ }^{* *}-p \geq 0,99,{ }^{* * *}-p \geq 0,999$

З даних таблиці видно, що телиці дослідних груп за показниками живої маси у всі вікові періоди перевищували ровесниць контрольної групи 3 достовірною різницею. Серед дослідних груп беззаперечна перевага була у тварин III дослідної групи.

Така ж тенденція спостерігається і за показниками середньодобових та відносних приростів.

Лінійні проміри тіла телиць у 18-місячному віці $\overline{\boldsymbol{X}}_{ \pm} \boldsymbol{S} \overline{\boldsymbol{X}}$

\begin{tabular}{|c|c|c|c|c|}
\hline \multirow{2}{*}{ Проміри } & \multicolumn{4}{|c|}{ Група, $n=10$} \\
\hline & $\mathrm{I}$ & II & III & IV \\
\hline Висота в холці & $125,5 \pm 0,61$ & $124,0 \pm 0,49$ & $126,3 \pm 0,47$ & $125,2 \pm 0,38$ \\
\hline Висота в крижах & $125,3 \pm 0,68$ & $127,1 \pm 0,76$ & $130,2 \pm 0,84^{\star * *}$ & $129,0 \pm 0,81^{* *}$ \\
\hline Глибина грудей & $62,9 \pm 0,69$ & $61,8 \pm 0,53$ & $68,2 \pm 0,46^{* * *}$ & $65,7 \pm 0,49^{* *}$ \\
\hline Коса довжина тулуба & $145,1 \pm 0,95$ & $148,0 \pm 0,90^{*}$ & $155,1 \pm 0,84^{* * *}$ & $151,9 \pm 0,97^{\star \star \star}$ \\
\hline Обхват грудей & $178,1 \pm 0,73$ & $179,0 \pm 0,95$ & $195,3 \pm 0,89^{* * *}$ & $190,7 \pm 0,97^{\star \star \star}$ \\
\hline Обхват п'ястка & $19,2 \pm 0,32$ & $20,3 \pm 0,36^{*}$ & $20,9 \pm 0,27^{* * \star}$ & $20,7 \pm 0,26^{\star \star}$ \\
\hline Напівобхват заду & $125,0 \pm 0,44$ & $127,1 \pm 0,37^{\star \star}$ & $130,2 \pm 0,32^{\star \star \star}$ & $128,9 \pm 0,43^{\star \star \star}$ \\
\hline Ширина грудей & $42,3 \pm 0,59$ & $42,1 \pm 0,45$ & $50,2 \pm 0,44^{* \star *}$ & $49,1 \pm 0,64^{* * *}$ \\
\hline Ширина в маклаках & $38,0 \pm 0,47$ & $36,7 \pm 0,30^{*}$ & $41,9 \pm 0,31^{* * *}$ & $41,1 \pm 0,34^{* * *}$ \\
\hline
\end{tabular}




\begin{tabular}{|c|c|c|c|c|}
\hline $\begin{array}{c}\text { Ширина тазостегнових } \\
\text { зчленуваннях }\end{array}$ & $37,2 \pm 0,44$ & $38,1 \pm 0,40$ & $43,8 \pm 0,24^{* * *}$ & $43,0 \pm 0,39^{* * *}$ \\
\hline \multicolumn{4}{|c|}{ Примітки: ${ }^{*}-p \geq 0,95,{ }^{* *}-p \geq 0,99,{ }^{* * *}-p \geq 0,999$} \\
\hline
\end{tabular}

Порівнюючи проміри тіла телиць різних дослідних груп можна відмітити перевагу тварин III дослідної групи за всіма висотними та широтними показниками (різниця статистично достовірна). Інші три групи мали нижчі і досить близькі показники. В цілому тварини достатньо крупні, гармонійно складені, із міцним, але не масивним кістяком, що підтверджується показниками індексів будови тіла тварин (рис. 1).

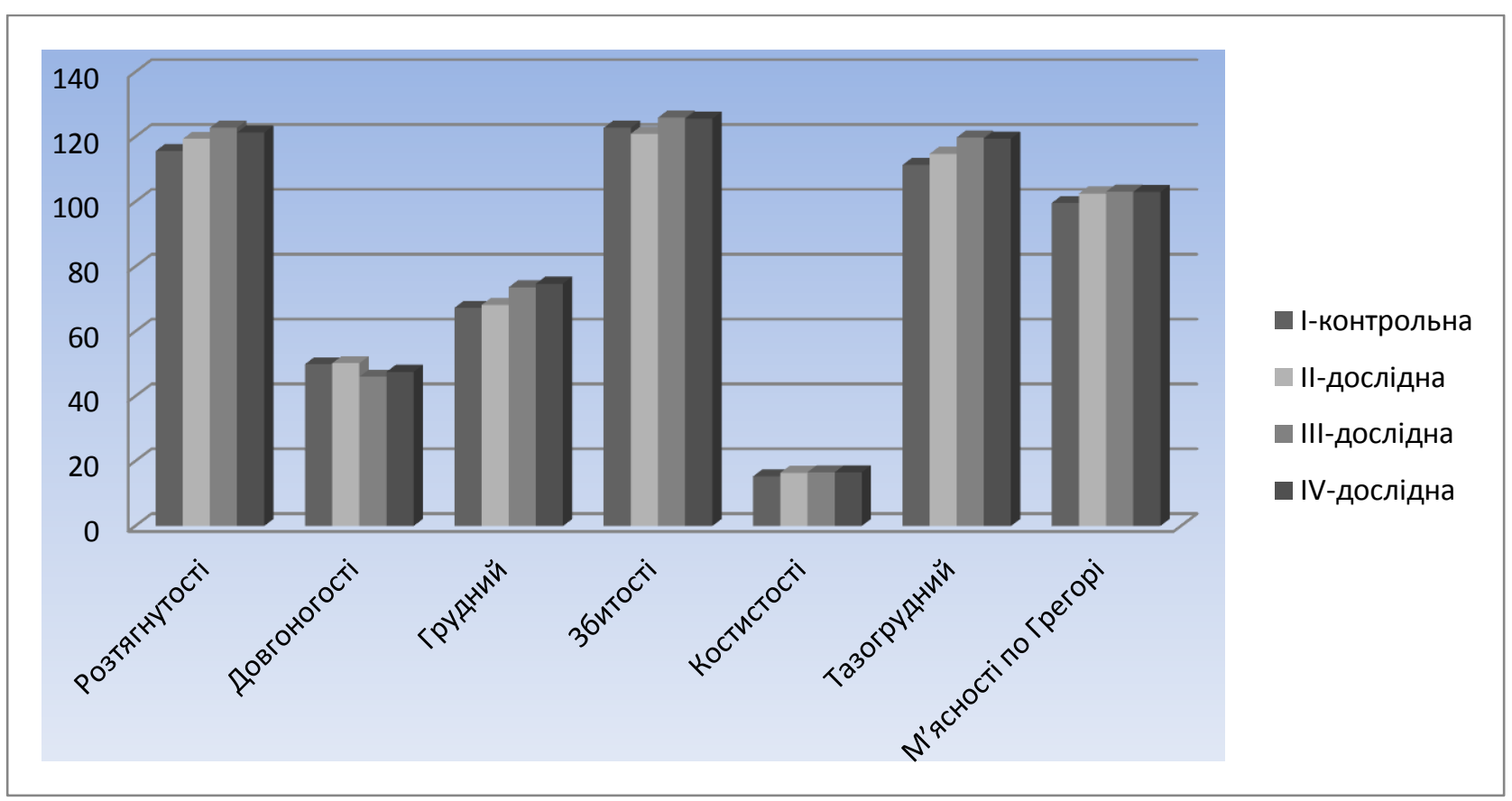

Рис. 1. Індекси будови тіла телиць

За індексами будови тіла вищу оцінку, отримали телиці III і IV дослідних групи . Вони мали вищі показники за такими індексами будови тіла як грудний, збитості, що характеризує їх кращі м'ясні форми.

Енергія росту тварин у м'ясному скотарстві це показник який безпосередньо впливає на відтворювальну здатність, бо повноцінно розвинена тварина здатна доволі рано досягти статевої зрілості та давати здорове потомство кожен рік. За показниками відтворювальної здатності встановлено, що між телицями різного походження $є$ певні відмінності (табл. 3).

Таблиця 3

Характеристика відтворювальної здатності телиць, $\left(\bar{X}_{ \pm} \boldsymbol{S} \overline{\boldsymbol{x}}_{)}\right.$

\begin{tabular}{|l|c|c|c|c|}
\hline \multicolumn{1}{|c|}{ Показник } & \multicolumn{4}{|c|}{ Група, $n=10$} \\
\cline { 2 - 5 } & $\mathrm{I}$ & II & III & IV \\
\hline $\begin{array}{l}\text { Жива маса, кг: } \\
\text { при прояві першої охоти }\end{array}$ & $230,4 \pm 1,32$ & $277,8 \pm 4,55^{* * *}$ & $333,9 \pm 5,45^{* * *}$ & $303,6 \pm 5,05^{* * *}$ \\
\hline $\begin{array}{l}\text { при першому плідному } \\
\text { осіменінні }\end{array}$ & $360,0 \pm 3,42$ & $363,9 \pm 4,52$ & $393,2 \pm 4,95^{* * *}$ & $381,1 \pm 3,04^{* * *}$ \\
\hline при отеленні & $440,1 \pm 2,57$ & $445,0 \pm 5,06$ & $465,3 \pm 3,13^{* * *}$ & $442,0 \pm 4,36$ \\
\hline Тривалість тільності, діб & 285 & 282 & 285 & 284 \\
\hline
\end{tabular}

Примітки: ${ }^{* * *}-p \geq 0,999$

Аналізуючи дані таблиці 3 видно, що тварини усіх генотипів при прояві першої охоти мали доволі різні показники живої маси. Найбільша 333,9 кг була у тварин III дослідної групи, а найнижча 230,4 кг у I контрольної. Телиці III-дослідної групи також характеризувались вищим показником заплідненості від першого парування порівняно з ровесницями інших груп при достовірній різниці ( $p \geq 0,999)$. За показникам тривалості тільності суттєвої різниці між генотипами не встановлено. 


\section{Висновки}

1. Встановлено, що за умов однакової годівлі та утримання телиці III дослідної групи проявляли більш високу енергію росту і досягли у 18-місячному віці живої маси 465,3 кг, I контрольної, II дослідної і IV дослідної відповідно 370,2 кг, 440,7 кг і 455,4 кг, або на 95,1, 24,6 і 9,9 кг менше при статистично вірогідній різниці $(p \geq 0,999)$.

2. За результатами досліджень можна констатувати, що телиці дослідних груп характеризувалися значною різноманітність промірів тіла. За грудним та індексом збитості тварини III дослідної та IV дослідної групи отримали найвищу оцінку, що характеризують їх кращі м'ясні форми.

3. Доведено, що телиці III дослідної групи при прояві першої охоти мали найвищу живу масу 333,9 кг що на103,5 кг, 56,1кг,30,4 кг більше ніж тварин I, II та IV груп. Тенденція переваги III групи за живою масою при першому плідному осіменінні та живій масі при отеленні також спостерігається.

Перспективи подальших досліджень.

Подальше використання тварин знам'янського типу поліської м'ясної породи різного лінійного походження можливо при закріпленні отриманих показників росту, розвитку та відтворювальної функції телиць. Тварини усіх ліній за конституційними характеристиками максимально наближені до м'ясного типу худоби, але за показниками живої маси при першому прояві охоти та першому плідному осіменінні деякі лінії поступаються тваринам лінії Радиста 113. Отже у подальшій роботі при удосконаленні знам'янського типу можливе використання тварин лінії Радиста 113 для покращення цих показників.

\section{References}

Dibrova, A., \& Kukhar, O. (2014). State support for the development of cattle breeding in Ukraine. Challenges for the Agricultural Sector in Central and Eastern Europe. 123-137. doi: 10.18515/dBEM.M2014.n01.ch08.

Gladij, M. V., \& Sychevs'kyj, M. P. (2018). Meat-processing industry of Ukraine in the global food system. Agrovisnyk, 5, 5-11. doi.org/10.31073/agrovisnyk201805-01.
Gokirmakli, C., \& Bayram, M. (2017). Future of meat industry. MOJ Food Process Technol., 5(1), 232238. doi: 10.15406/mojfpt.2017.05.00117.

Greenwood, P., Clayton, E., \& Bell, A. (2017). Developmental programming and beef production. Animal Frontiers, 3(3), 38-47. doi.org/10.2527/af.2017-0127.

Gregory, N. G. (2007). Animal welfare and the meat market. Animal welfare and meat production. $C A B$ International, Wallingford, Oxfordshire, UK, 1-21. doi:10.1079/9781845932152.0001.

Herring, A. (2014). Beef cattle production systems. Texas A \& M University, College Station, Texas, USA. doi 10.1079/9781780645070.0001.

Hladiy, M. V., Polupan, Y. P., Kovtun, S. I., \& Borodai, I. S. (2018). Naukova shkola akademika M. V. Zubtsya u rozvytku naukovykh osnov vitchyznyanoho tvarynnytstva. Animal Breeding and Genetics, 55, 613. doi.org/10.31073/abg.55.01. (in Ukrainian)

Honcharova, I. I. (2006). Intensyvnist vyroshchuvannia telyts znam'ianskoho m'iasnoho typu - vazhlyvyi faktor porodoutvoriuvalnoho protsessu .Nauk. Visnyk Lvivskoi natsionalnoi akademii veterynarnoi medytsyny im. S.Z. Hzhytskoho, 30-32. (in Ukrainian)

Kernasiuk, Y. V. (2016). Rynok m'iasa VRKh v Ukraini: problemy i perspektyvy. .Ahrobiznes sohodni, 8, 1417. (in Ukrainian)

Kruglyak, O. V., \& Martynyuk, I. S. (2016). Economic bases of gene pool of local and endangered breeds of farm animals species preservation in Ukraine. Animal Breeding and Genetics, 52, 211-220. doi.org/10.31073/abg.52.28. (in Ukrainian)

Pidorycheva, I. Yu. (2014). Innovative Activity in the Industry of Ukraine: Problems, Risks, and Directions of Stepping. Science and Innovation, 10, 57-64. doi.org/10.15407/scine10.05.057.

Pochukalin, A. Y., Reznikova, Y. M., Pryima, S. V., \& Rizun, O. V. (2016). Selektsiine nadbannia m'iasnoho skotarstva Ukrainy: znam'ianskyi vnutrishnoporodnyi typ poliskoi m'iasnoi porody. Rozvedennia i henetyka tvaryn, 52, 94-108. doi.org/10.31073/abg.52.12. (in Ukrainian)

Polupan, Y. P., Basovskyi, D. M., Rieznykova, N. L., \& Reznikova, Y. M. (2017). Problema zberezhennia biolohichnoho riznomanittia henetychnykh resursiv silskohospodarskykh tvaryn. Rozvedennia $i$ 
henetyka tvaryn, 54, 200-208. doi.org/10.31073/abg.54.26. (in Ukrainian)

Prudnikov, V. H., \& Popova, V. O. (2001). Hospodarskobiolohichni osoblyvosti znam'ianskoi m'iasnoi porody. Visnyk Sumskoho derzhavnoho ahrarnoho universytetu, 5, 148-151. (in Ukrainian).

Prudnikov, V., Popova, V., \& Tsukanova, M. (2018). Problemy selektsiinoho protsesu $v$ m'iasnomu skotarstvi na suchasnomu etapi. Ahrarna nauka ta osvita $v$ umovakh Yevrointehratsii, 270-272. (in Ukrainian)

Reznikova, Y. M. (2016). Comparative characteristics of ukrainian grey cattle and some specialized beef breeds by economically valuable traits. Animal Breeding and Genetics, 52, 221-227. doi.org/10.31073/abg.52.29.

Sen, O., Ruban, S., Getya, A., \& Nesterov, Y. (2014). Current state and future outlook for development of the milk and beef sectors in Ukraine. EAAP Scientific,135, 169-180. doi.org/10.3920/978-908686-785-1 13.

Shust, O. (2018). Features of consumer behavior in the market of meat cattle breeding in Ukraine. International Scientific Days 2018. Towards Productive, Sustainable and Resilient Global Agriculture and Food Systems. Conference Proceedings, (683-696). Prague. doi.org/10.15414/isd2018.s2-3.10.

Suprun, I. A., Ruban, S. Yu. \& Getya, A. A. (2016). Development status of meat cattle in Ukraine. Bulg. J. Agric. Sci., 22, 140-142. Retrieved from https://www.agrojournal.org/22/01s-26.pdf

Vlasova, K. (2015). Current Development of MeatProcessing Industry in Ukraine: Tendencies, Problems and Strategies for Solution. European Researcher, 98, 637-646. doi: 10.13187/er.2015.98.637.

Zinovchuk, V., \& Rud, V. (2016) Veritical integration in meat industry: case of Ukraine. Management Theory and Studies for Rural Business and Infrastructure Development, 38, 88-99. doi: $\underline{10.15544 / \mathrm{mts} .2016 .8,20 .}$. 